\title{
ANALISIS PENDEKATAN SEMIOTIKA DALAM PUISI-PUISI JOKO PINURBO DENGAN TEMA "KEMATIAN"
}

\author{
Wida Nurul Rachma ${ }^{1)}$, Een Nurhasanah ${ }^{2}$, Slamet Triyadi ${ }^{3)}$ \\ Universitas Singaperbangsa, Karawang \\ 1710631080165@student.unsika.ac.id
}

ABSTRAK

ABSTRACK
Tujuan dari penelitian ini adaalah untuk menganalis kebermaknaan yang terkandung pada teks-teks puisi karya Joko Pinurbo dalam batasan untuk mendeskripsikan analisis semiotik dan mendeskripsikan hasil analisis semiotik pada puisi-puisi karya Joko Pinurno. Puisi-puisi yang digunakan hanya lima puisi dengan judul, yaitu Pulang Malam, Ranjang Putih, Aku Tidur Di Remang Tubuhmu, Calon Jenazah, dan Prosesi. Metode yang digunakan adalah metode deskriptif kualitatif, dengan menjelaskan hasil analisis dari unsur pembangun puisi, hasil analisis semiotika pada puisi-puisi yang dipilih, dan hasil analisis semiotika yang dijadikan sebagai rekomendasi ide dan konsep pembelajaran bahasa Indonesia. Berdasarkan hasil analisis, dalam puisi-puisi Joko Pinurbo memiliki tiga tema kematian, yaitu tema kematian bukan sebenarnya (keromantisan), tema kematian (kehilangan semangat), dan tema kematian sebenarnya; dua jenis kalimat, yaitu kalimat tunggal, dan kalimat majemuk; dua majas yang digunakan, yaitu majas metafora, dan majas personifikasi tipografi yang berbeda, dan tujuh macam isotopi, yaitu isotopi pronomina, isotopi perbuatan, isotopi alam, isotopi waktu, isotopi penghubung, isotopi manusia, dan isotopi tempat. Analisis semiotik ini bisa digunakan atau direkomendasikan sebagai ide, dan konsep pembelajaran yang disesuaikan pada tingkatan pendidikan Sekolah Menengah Atas kelas X sesuai dengan materi pada buku Bahasa Indonesia mengenai Puisi.

Kata Kunci: analisis semiotik, puisi, dan tema kematian

The purpose of this research is to analyze the meaning contained in the texts of poems by Joko Pinurbo within the limits to describe semiotic analysis and describe the results of semiotic analysis on poems by Joko Pinurno. The poems used are only five poems with the title, namely Pulang Malam, Ranjang Putih, Aku Tidur Di Remang Tubuhmu, Calon Jenazah, and Prosesi. The method used is qualitative descriptive method, by explaining the results of analysis of the elements of poetry builders, semiotic analysis results in selected poems, and semiotic analysis results that serve as recommendations of ideas and concepts of learning Indonesian language. Based on the results of the analysis, in the poems Joko Pinurbo has three themes of death, namely the theme of death not actual (romance), the theme of death (loss of spirit), and the theme 
of actual death; two types of sentences, namely single sentences, and compound sentences; two majas used, namely metaphorical majas, and different typographic personification majas, and seven kinds of isotopi, namely isotopi pronomina, isotopi deeds, isotopi nature, isotopi time, isotopi liaison, isotopi man, and isotopi place. This semiotic analysis can be used or recommended as an idea, and the concept of learning is adjusted at the level of high school education grade $\mathrm{X}$ in accordance with the material in the Book of Indonesian Language on Poetry.

Keywords : semiotic analysis, poetry, and themes of death

\section{PENDAHULUAN}

Puisi merupakan salah satu karya sastra yang bahasanya masih terikat oleh irima, mantra, rima serta penyusunan larik dan bait. Di dalam puisi juga terdapat makna atau simbol yang tersirat guna sebagai pesan untuk para pembaca mengenai hal yang ingin disampaikan penulis melalui sebuah puisi. Oleh karena itu dari puisi kita bisa mengetahui hubungan antar tanda, hubungan antara tanda dan makna, serta hubungan antara tanda dan pemakai tanda. Puisi-puisi yang dipilih adalah puisi karya Joko Pinurbo yang memiliki benang merah yang sama atau saling berkaitan. Puisipuisi yang dipilih, sebagai berikut Pulang Malam dalam buku Selamat Menunaikan Ibadah Puisi yang terbit pada tahun 2017, Ranjang Putih dalam buku Malam Ini Aku Akan Tidur Dimatamu yang terbit tahun 2016, Calon Jenazah dalam buku Buku Latihan Tidur yang terbit tahun 2017, Aku Tidur di Remang Tubuhmu dalam buku Kekasih Ku yang terbit tahun 2004, dan Prosesi dalam buku Bulu Matamu: Padang Ilalang yang terbit tahun 2019.

Hal yang melatar belakangi pemilihan karya sastra puisi adalah peneliti akan menganalisis tiga aspek semiotika dari puisipuisi tersebut serta benang merah atau tema kematian dirasa menarik karena sejauh ini tema tersebut jarang digunakan didalam penelitian-penelitian sebelumnya. Walaupun didalam buku-buku kumpulan puisi yang dibaca oleh peneliti memiliki berbagai tema atau benang merah, seperti tema sosial, tema percintaan, dan tema ibu.

Oleh karena itu, peneliti mengindentifikasikan masalah yang akan dijadikan bahan penelitian yaitu, tema dalam puisi-puisi karya Joko Pinurbo, analisis unsur-unsur puisi, analisis pendekatan semoiotika yang terdiri dari tiga aspek, yaitu aspek semantik, aspek sintaksis, dan aspek pragmatik, dan hasil analisis ini dapat dijadikan sebagai gambaran konsep pembelajaran puisi. Teori yang digunakan untuk analisis, yaitu teori Aart Van Zoest dengan langkah kerja analisis (dalam Okke, 2014: 48-81, yaitu: aspek sintaksis mengemukakan hubungan antar unsur-unsur yang ada dalam teks, seperti kalimat, aspek semantik mengemukkan hubungan antara unsur-unsur yang hadir dalam teks dengan acuan, seperti denotasi dan konotasi, majas, dan isotopi, dan aspek semantik, yaitu hubungna antara tanda dan pemakai tanda, seperti deikis pronomina. 
Selain itu juga peneliti menemukan analisis serupa yang menggunakan pendekatan semiotika dalam analisisnya, yaitu pertama analisis puisi Heri Isnaini yang berjudul Perangko. Penelitian ini bertujuan untuk (1) menganalisis puisi tersebut secara semiotik, (2) mendeskripsikan hasil analisis puisi berjudul "Prangko" (3) mendeskripsikan pokok-pokok masalah pada tema puisi tersebut (Putri, Puspitasari, \& Permana, 2019).

Kedua, analisis semiotik puisi Chairil Anwar. Tujuan yang ingin dicapai dari tulisan ini adalah mengetahui makna dari teksteks puisi Chairil Anwar. Beberapa puisi Chairil Anwar sarat dengan bahasa kiasan yang berupa ungkapan khas milik Chairil yang selalu didengungdengungkan oleh generasi muda. Selain itu, puisi-puisi Chairil juga memiliki unsur-unsur kepuitisan yang menimbulkan bunyi yang indah apabila dibacakan (Saptawuryandani, 2013).

Ketiga, analisis makna pada puisi Kamus Kecil karya Joko Pinurbo. Tujuan dari penelitian ini untuk menganalisis makna dalam puisi karya Joko Pinurbo atau yang akrab dengan Jokpin berjudul "Kamus Kecil". Selain itu puisi ini dibedah menggunakan pendekatan simiotik yang mengerucut pada teori sassure tentang pengembangan ilmu linguistik (Fatimah, Sadiah, \& Permana, 2019).

Keempat, analisis stukutur batin puisi Sesamar Kasih Pencari Rezeki. Pemilihan puisi namaini didasarkan pada struktur batin dan struktur fisik puisi yang menarik untuk dikaji lebih jauh. Puisi tersebut mengandung maksud kompleksitas berkaitan dengan bahasanya yang ingin disampaikan oleh pengarang (Sebayang, 2018).

Kelima, analisis mengenai makna kematian di dalam puisi puisi Joko pinurbo. Penelitian ini mendeskripsikan makna puisi Joko Pinurbo yang berpotensi menggambarkan kematian dengan menggunakan analisis semiotika yaitu ilmu tentang tanda (Azhari, 2014).

Analisis semiotika ini dirasa cocok untuk menggali lebih dalam tentang puisi-puisi karya Joko Pinurbo ini dan jika diimplentasikan kepada siswa, maka siswa akan mampu mengetahui hal-hal yang tersirat di dalam puisi-puisi yang dibaca. Selain karena kebutuhan penelitian, karya sastra puisi ini adalah sesuatu yang menarik dan disukai.

Penelitian ini peneliti menggunakan metode deskriptif kualitatif. metode ini menjelaskan hasil analisis dari unsur pembangun puisi, hasil analisis semiotika pada puisi-puisi yang dipilih, dan hasil analisis semiotika yang dijadikan sebagai materi bahan ajar. Langkah-langkah analisis sebagai berikut, pertama membaca puisi-puisi yang telah dipilih, kedua menganalisis stuktur batin dan struktur fisik pada puisi-puisi yang dipilih, ketiga menganalisis aspek sintaksis, yaitu mencari berapa kalimat disetiap puisi, kemudian mencari subjek, predikat, objek, keterangan waktu dan keterangan suasana, keempat menganalisis aspek semantik, yaitu mencari kata yang berkonotasi, kata yang 
bedonatasi, kemudian mengkelompokkan kata ke dalam isotopiisotopi yang telah ditentukan, kelima, menganalisis aspek pragmatik, yaitu mencari hubungan antara tanda dan pemakai tanda, atau maksud yang dibuat oleh penulis puisi, keenam tahap akhir, analisis ini kemudian bisa digunakan atau direkomendasikan sebagai ide, dan konsep bahan pembelajaran khususnya untuk pengajar yang disesuaikan pada tingkatan pendidikan Sekolah Menengah Atas kelas X sesuai dengan materi pada buku Bahasa Indonesia mengenai Puisi.

\section{PEMBAHASAN}

\section{Deskripsi Hasil Penelitian}

Penelitian ini dilakukan pada puisi Pulang Malam, Ranjang Kematian, Calon Jenajah, Aku Tidur di Remang Tubuhmu, dan Prosesi karya Joko Pinurbo. Berikut data yang diperoleh, puisipuisi karya Joko Pinurbo memiliki tiga makna kematian, yaitu makna kematian sebagai hal romatis terdapat puisi Pulang Malam dan puisi Ranjang Putih, makna kematian sebagai hal hilangnya semangat terdapat pada puisi Aku Tidur di Remang Tubuhmu, dan makna kematian sebenarnya pada puisi Calon Jenazah dan Prosesi.

Kemudian, imaji yang dihasilkan pada puisi-puisi ini adalah imaji visual, imaji suara, dan imaji raba atau sentuh. Setelah menanalisis aspek sintaksis ada dua bentuk kalimat yang digunakan, yaitu kalimat tunggal dan 23 kalimat majemuk yang terdiri dari kalimat majemuk setara dengan klausa rapatan, kalimat majemuk koordinatif dan kalimat majemuk subordinatif. Dan dalam dua puisi memiliki kalimat langsung yang ditandai dengan tanda kutip dan tanda seru. Penggunaan kata konkret dalam setiap puisi-puisi yang dianalisis berfungsi untuk mempertegas imaji visual, imaji suara, dan imaji raba atau sentuh pada puisi-puisi karya Joko Pinurbo.

Kemudian, dalam analisis semantik pada bagian isotopi terdapat tujuh jenis isotopi yang telah dikelompokkan disetiap puisi-puisi. Pengelompokkan ini berdasarkan apa yang ada di dalam puisi, seperti pronomina, perbuatan, waktu, manusia, pnghubung, tempat, dan alam.

Pada tahap akhir, yaitu analisis aspek pragmatik, peneliti menganalisis pada bagian deiksis yang merupakan pengguanaan pronomina untuk menyampaikan kisah maupun pengalaman aku lirik pada puisi-puisi tersebut. Pronomina (kata ganti orang) yang digunakan dalam puisi-puisi karya Joko Pinurbo, yaitu pronomina persona pertama jamak, pronomina persona kedua tunggal, dan pronomina persona ketiga tunggal. Namun, pada puisi Prosesi tidak menggunakan pronomina, akan tetapi menggunakan kata julukan yang diperkuat dengan kata sandang

\section{Pembahasan Hasil Penelitian}

Setelah mendeskripsikan hasil penelitian, berikut alur pembahasan yang dihasilkan pada puisi-puisi karya Joko Pinurbo menggunakan teori Art van Zoest, dan dikembangkan oleh dalam buku Kusuma Okke Sumantri Zaimar: 
Struktur batin pada lima puisi karya Joko Pinurbo yang bertema kematian, bahwa ada tiga makna kematian pada puisipuisi tersebut, yaitu makna kematian yang romatis (bukan makna sebenarnya) terdapat pada puisi Pulang Malam, dan puisi Ranjang Putih, makna kematian sebenarnya terdapat pada puisi Calon Jenazah, dan Puisi Prosesi, dan makna kematian yang kehilangan semangat (bukan makna sebenarnya) pada puisi Aku Tidur di Remang Tubuhmu.

Struktur fisik pada lima puisi kaarya Joko Pinurbo, memilki tipografi yang berbeda disetiap puisinya. Diksi yang digunakan pada puisi Pulang Malam, pada tubuh kami, hangus dan membangkai, kekal berpelukan, tidur damai, puisi Ranjang Putih, pada pulang, ke haribaan ranjang, ke teluk persinggahan, Puisi Calon Jenazah pada calon jenazah, yang mulia, selamat mandi, ajal memeluknya, Puisi Aku Tidur di Remang Tubuhmu, pada terbungkus kabur, dan mati, Puisi Prosesi iringan jenazah, tengah malam, di keranda dan si mati mabuk.

Kata konkret dalam puisi-puisi karya Joko Pinurbo, yaitu Puisi Pulang Malam, yaitu tubuh, membangkai, melumatnya, kekal, damai, dekapan. Puisi Ranjang Putih, yaitu dibersihkan, diredakan, disenyapkan, kesunyian. Puisi Calon Jenazah, yaitu calon, jenazah, mulia, kungkum, bak mandi. Puisi Aku Tidur di Remang Tubuhmu, yaitu lelap, ombak, deru, tidur, remang, tubuhmu. Puisi Prosesi, yaitu iringan, jenazah, gerimis, sepanjang, jalan.

\section{Temuan Aspek Semiotik \\ Aspek Sintaksis}

Pada puisi Pulang Malam terdiri dari tiga bait dengan banyaknya larik berjumlah 12 larik. Bait pertama berjumlah empat larik, bait kedua berjumlah lima larik, sedangkan bait ketiga berjumlah tiga larik. Penggunaan huruf kapital pada bait pertama dilarik pertama dan kedua, bait kedua awal larik, dan bait ketiga awal larik. Selain itu terdapat tanda baca titik disetiap baitnya. Jumlah kalimat yang membangun puisi "Pulang Malam", yaitu empat kalimat. Kalimat tunggal berjumlah satu kalimat, dan kalimat majemuk koodinatif berjumlah tiga kalimat.

Puisi "Ranjang Putih" terdiri dari empat bait dengan banyaknya larik berjumlah 14 larik. Bait pertama, bait kedua, dan bait ketiga berjumlah empat larik, sedangkan bait keempat berjumlah dua larik. Pada bait pertama, dan ketiga menggunakan huruf kapital disetiap lariknya, sedangkan pada bait kedua, dan keempat penggunaan huruf kapital hanya di awal larik. Penggunaan tanda baca titik digunakan disetiap baitnya, dan tanda baca koma hanya dibait ke ketiga. Selain itu, di dalam teks puisi ini terdapat tanda nonbahasa (-) yang terdapat pada bait ketiga. Jumlah kalimat yang membangun puisi "Ranjang Putih", yaitu tujuh kalimat. Kalimat tunggal yang membangun teks puisi ini berjumlah lima kalimat, kalimat majemuk koordinatif berjumlah satu kalimat, dan kalimat majemuk subordinatif berjumlah satu 
kalimat.

Puisi "Calon Jenazah" terdiri atas dua bait dengan jumlah larik berjumlah 17 larik. Bait pertama berjumlah delapan larik, dan bait kedua berjumlah sembilan larik. Dalam teks puisi ini digunakan huruf kapital pada bait pertama dilarik pertama, dan larik ketiga, dan pada bait kedua dilarik pertama, larik keempat, larik ke lima, larik ke enam, larik ketujuh, dan larik kedelapan. Tanda baca titik, dan tanda baca koma terdapat pada dikedua bait. Selain itu terdapat nonbahasa titik dua, tanda kutip dua untuk menunjukan kalimat langsung. Jumlah kalimat yang membangun puisi "Calon Jenazah", yaitu sembilan kalimat. Kalimat tunggal berjumlah tiga kalimat, kalimat majemuk setara (klausa rapatan) berjumlah satu kalimat, kalimat majemuk subordinatif berjumlah tiga kalimat, dan kalimat majemuk koordinatif berjumlah dua kalimat.

Puisi "Aku Tidur di Remang Tubuhmu" memiliki satu bait puisi yang berisi lima larik puisi. Dalam teks puisi ini digunakan huruf kapital pada larik pertama, larik ketiga, larik keempat, dan larik ke lima. Tanda baca titik terdapat pada larik kedua, larik ketiga dan larik kelima, dan tanda baca koma terdapat pada larik keempat. Tanda kutip dua dan tanda seru untuk menunjukkan kalimat langsung. Jumlah kalimat yang membangun puisi "Aku Tidur di Remang Tubuhmu",yaitu empat kalimat. Kalimat majemuk subordinatif berjumlah dua kalimat, kaliamat majemuk setara (klausa rapatan) berjumalh satu kalimat, dan kalimat tunggal berjumlah satu kalimat.

Puisi "Prosesi" memiliki enam larik puisi dalam tiga bait. Dalam teks puisi ini menggunakan huruf kapital disetiap baitnya, yaitu pada bait pertama, bait kedua, dan pada bait ketiga hanya diawal larik saja. Pada teks puisi ini hanya mengguankan tanda baca titik pada setiap baitnya. Jumlah kalimat yang membangun puisi "Prosesi", yaitu lima kalimat. Kalimat tunggal berjumlah empat kalimat, dan kalimat majemuk subordinatif berjumlah satu kalimat.

\section{Aspek Semantik}

Majas yang digunakan dalam puisi-puisi karya Joko Pinurbo yaitu majas personifikasi dan majas metafora. Majas personifikasi adalah majas yang digunakan dengan mengganti sifat benda mati dengan sifat seperti manusia sedangkan majas metaforaa adalah majas yang memakai analogi atau perumpamaan terhadap dua hal yang berbeda.

\section{Aspek Pragmatik}

Analisis Deiksis

Puisi "Pulang Malam" menggunakan pronomina pertama jamak kami mengacu pada aku lirik untuk mempertagas bahwa kami adalah sepasang kekasih atau suami istri.

Puisi "Ranjang Putih" menggunakan pronomina persona kedua tungga ini mengacu pada aku lirik untuk mempertegas 
bahwa -mu dan kau adalah seseorang yang ingin hidup abadi bersama pasangannya.

Puisi "Calon Jenazah" menggunakan pronomina persona kedua tunggal ini mengacu pada aku lirik untuk mempertegas bahwa -mu dan kau adalah seseorang yang ingin hidup abadi bersama pasangannya.

Puisi "Aku Tidur di Remang Tubuhmu" menggunakan pronomina persona pertama tunggal dan pronomina kedua tunggal ini mengacu pada aku lirik untuk mempertegas bahwa aku dan kau adalah sepasang kekasih yang memiliki masalah, namun salah satunya sedang kehilangan semangat.

Puisi "Prosesi" tidak menggunakan pronomina (kata ganti orang), melainkan dengan kata julakan mati yang berarti tidak bernyawa, dan diperkuat untuk menyatakan subjek pada teks puisi oleh kata sandang si.

SIMPULAN

Berdasarkan hasil analisis, dalam puisi-puisi Joko Pinurbo, dapat disimpulkan tema kematian pada puisi-puisi memiliki tiga jenis tema kematian, yaitu tema kematian bukan sebenarnya (keromantisan), tema kematian bukan sebenarnya (kehilangan semangat), dan tema kematian sebenarnya; hasil analisis aspek sintaksis memidua jenis kalimat, yaitu kalimat tunggal, dan kalimat majemuk; hasil anlisis semantik memilki dua majas yang digunakan, yaitu majas metafora, dan majas personifikasi; dan tujuh macam isotopi, yaitu isotopi pronomina, isotopi perbuatan, isotopi alam, isotopi waktu, isotopi penghubung, isotopi manusia, dan isotopi tempat; analisis prarmatik, menggunakan pronomina pertama tunggal, pronominan pertama jamak, pronomina kedua tunggal, dan menggunakan kata julukan yang diperkuat dengan kata sandang

Analisis pendekatan kualitatif merupakan analisis yang melahirkan sebuah ide, konsep atau masukan, oleh karena itu analisis semiotik pada puisi-puisi karya Joko Pinurbo dengan mengambil tema kematian bisa digunakan atau direkomendasikan sebagai ide, dan konsep bahan pembelajaran khususnya untuk pengajar yang disesuaikan pada tingkatan pendidikan Sekolah Menengah Atas kelas X sesuai dengan materi pada buku Bahasa Indonesia mengenai Puisi. 


\section{DAFTAR PUSTAKA}

Azhari, W. (2014). Makna Kematian Dalam Puisi-Puisi Joko Pinurbo Melalui Pendekatan Semiotika. GARUDA (Garda Rujukan Digital), II(2).

Fatimah, D. S., Sadiah, S. H., \& Pramardhika, R. B. (2019). Analisis Makna Pada Puisi "Kamus Kecil" Karya Joko Pinurbo Menggunakan Pendekatan Semiotika. Parole Pendidikan Bahasa dan Sastra Indonesia, II(5), 701-706.

Nurhasanah, E. (2016). Pengantar Kajian Kesusastraan (Diktat). Pendidikan Bahasa dan Sastra Inonesia FKIPUNSIKA.

Putri, P. N., Puspitasari, T., \& Permana, I. (2019). Analisis Puisi Heri Isnaini "Perangko" Dengan Pendekatan Semiotika. Parole Pendidikan Bahasa dan Sastra Indonesia, II(3), 365-370.

Sebayang, S. K. (2018). Analisis Struktur Batin Puisi Sesamar Kasih Pencari Rezeki Karya Dewi Ayu Utami Nasution. Jurnal UNIMED, VII(1).

Septawuryandari, N. (2013). Analisis Semiotik Puisi Chairil Anwar (Semiotic Analysis of Chairil Anwar's Poems). KANDAI, IX(1), 95-104.

Zaimar, O. K. (2014). Semiotika dalam Analisis Karya Sastra. Depok: PT Komodo Books. 